\title{
Viral Pathogenesis
}

National Cancer Institute

\section{Source}

National Cancer Institute. Viral Pathogenesis. NCI Thesaurus. Code C19589.

A disease state resulting from virus infection. 